UDC 622.245

Ye. I. Kryzhanivskyi, Dr. Sc. (Tech.), Prof., orcid.org/0000-0001-6315-1277,

I. I. Paliichuk, Cand. Sc. (Tech.), Assoc. Prof., orcid.org/0000-0002-8443-2702,

H. D. Malyk, Cand. Sc. (Pedag.), Assoc. Prof., orcid.org/0000-0002-7815-454X

\title{
LARGE DEFORMATIONS OF THE CASING STRING UNDER ITS OWN WEIGHT IN THE CURVILINEAR WELL
}

Purpose. Determination of deformation and force parameters that describe the strain-stress state of the casing string in non-vertical well-bore areas.

Methodology. In a curvilinear well, the casing functions as a long permanent continuous rod. Its weight might cause some deformations that can be determined by a heterogeneous system of four differential equations. Taking into consideration the technological requirements for pipe installation on centralizers allows us to make the first integral of the system linear.

Findings. It is proved that the elastic rod deformation under the impact of the longitudinal and transverse forces of the distributed weight can be calculated by a heterogeneous second order differential equation with variable coefficients. Its solution is the clue to the formulas of deflections, angular slopes, internal bending moments and transverse forces in the rod with the arbitrary arrangement of supports and boundary conditions in their intersections.

Originality. The solution of the governing differential equation of angular deformations of a long bar is found in the form of a linear combination of Airy and Scorer's functions and in the form of three linearly independent polynomial series in the sum with a partial answer.

Practical value. The obtained formulas of flexure and power parameters allow us to calculate stress and strain in the tubing during the process of casing the bore-hole of an arbitrary profile which increases the reliability and durability of the well.

Keywords: curvilinear well, casing string, elastic rod, bending, Airy's functions, Scorer's functions

Introduction. The technology of reliable and safe petroleum extraction from deep deposits presupposes bore-hole walls to be cased with a steel pipe column and obligatory cementing of annular space to maintain the well-bore integrity, prevent or mitigate its collapse [1]. Modern methods of directional and horizontal drilling make it possible to reach productive layers at a depth of 4-7 km, with the string length extending to 7-10 km. Noteworthy, its diameter is only $168-140 \mathrm{~mm}$, whereas wall thickness is $10-12 \mathrm{~mm}$ [2]. Typical well-bore configurations include vertical, directional (with critically deviated vertical parts) and horizontal sections connected by transient curved passages [3]. As a rule, all column parts are on the same plane [4].

In well-bores, the casing rests on steel centralizers serving as hinge supports ensuring the coaxial positioning of pipes and walls forming a cement ring of the same thickness and strength between them [5]. Centralizers spaced at a distance of $10-20 \mathrm{~m}$ prevent excessive deflections and keep the casing from contacting with the hole walls in curved, sloping and horizontal sections [6]. Thus, the casing column functions as a long, permanent rod placed on centralizers and is subject to considerable geometric distortions of its axis replicating the well's curvilinear shape [7]. As a result, the pipe bodies are exposed to a complex stress-strain state caused by their bending and axial tension or compression, which decreases the casing reliability and durability [8]. Therewith, internal deformations of the

(C) Kryzhanivskyi Ye. I., Paliichuk I. I., Malyk H. D., 2018 metal should not exceed the proportional limit and Hooke's law.

Analysis of the recent research and publications. Generally, there is extensive research literature describing deformations of bars, beams, columns, rods, strings, and others. Mathematical tools depicting deformation problems outline the buckling issues relating to the casing weight and present practical applications in the casing string design and control.

Timoshenko and Gere [9] provided various solutions of elastic and inelastic buckling, namely: built-up columns, beams, curved bars, arches, rings. They established mathematical grounds to calculate the deflection of compressed members due to their weight, suggested alternate forms of differential equations (hereinafter DE) for load determining, applied DEs for lateral buckling, developed the beam-column theory modeling shear deformation and rotational bending effects in calculating critical loads.

Azar and Samuel [10] developed a model for calculating tension produced by the casing weight and string buckling conditioned by axial compression overloading. Eryılmaz et al. [11] applied homotopy analysis method to find the critical buckling loads for Euler columns with continuous elastic restraints by using linear and nonlinear, ordinary and partial DE, integral equations, difference equations, and others.

$\mathrm{Xu}$ and $\mathrm{Wu}$ [12] studied tubular string challenges in high-temperature, high-pressure oil and gas wells. They explored the string buckling behavior as well as load combinations resulting in string deformations and found 
a highly dimensional nonlinear DE model using the classical differential element analysis method.

Renpu [13] established solutions of casing buckling dependence on axial forces generated by several factors: casing weight, excessive flexural deformations caused by axial force decrease, axial tensile force, and the casing section weight. He proved that the buoyancy factor multiplied by the casing weight gives the buoyed weight of the casing.

Investigating buoyancy factor in terms of casing weight, Byrom [14] dealt with solutions depicting relation of stability for lateral buckling in tubular strings and eight parameters. Oriji and Anwana [15] explored the buoyed weight of the tubing per unit length in a directional well-bore. Xie [16] claimed that buoyant forces depend on the casing weight.

Hossain and Islam [17] gave an interesting interpretation of distributed buoyed weight of casing and showed its dependence on buckling force. Moreover, they studied the role of casing contact load, well-bore inclination angle, well-bore azimuth angle, pipe bending stiffness and radial annular clearness.

Jaculli and" Mendes [18] conducted research on the dynamic buckling models inside oil wells and reduction of the bottom hole assembly weight.

Nikolai (1916) and Popov (1948) made some calculations of double and single curvatures of a long elastic rod, yet they did not take into account the rod weight.

Frisch-Fay (1962) suggested a different approach to the problem. He formulated solutions of several problems concerning initially curved bars of uniform crosssection and uniform cantilever beams. He also studied the uniformly distributed loading by applying the series for a cantilever with one free edge only for vertical and horizontal fixing. His principle of elastic similarity explains how to cope with excessive bends of a flexible bar freely placed on two horizontal supports.

Kotskulych, et al. [5] concentrated on some aspects of deformed casing columns placed on centralizers in directional wells. Describing pipe deflections in the sections between the supports, the authors used a free supported rod with two free edges. However, they ignored longitudinal weight. In practice, the casing sections undergo mutual influence of their warps and forces in the supporting cross-sections. In order to find the necessary solution, the scientists used compatibility equations of rotation angles and bending moment equilibrium in adjacent intersections of the rod.

Vytvytskyi, et al. [6] focused on the study of inclined wells. They also viewed the casing string as a long elastic rod on supports and used the basic DE for rod deflections. The results obtained are identical to the wellknown solution of the permanent beam deformation under the distributed weight. Moreover, they take into account the rod placement at an indirect angle to the vertical. Nonetheless, they neglected the effect of longitudinal weight reaching large numerical values in real wells and definitely deforming casing pipes.

Unsolved aspects of the problem. As studies prove, scientists have tried to find exact buckling solutions of various strings, beams, bars, rods, frames and other structural elements. However, surprisingly enough, there is no general solution of the system of differential equations (hereinafter - SoDEs) determining deformations of a long elastic rod caused by its own longitudinal and transverse weight.

According to the analysis made in [19], Kirchhoff's rod theory uses a linear elastic law for bending and torsion and proves that large deformations produce geometric nonlinearities in the resulting equilibrium equations. Kirchhoff's SoDEs that describes the stress-strain state of a spatially curved rod is homogeneous with respect to its bending stiffness, whereas all force factors can be divided into $E J$ ( $E$ is an elastic modulus of the material; $J$ is a transverse rod moment of inertia). Consequently, regarding the equation universality, we can analyze large elastic buckling of a long rod with a single rigidity at its bend. The bending moment numerically equals rod curvature.

The objective of this article is to determine deformation and force parameters describing the casing stressstrain state in non-vertical wells. To achieve this, we specify the following aims: 1) to build and solve SoDEs for a long elastic rod bent under its own weight in one plane; 2) to investigate the governing integral of the system, which might help to obtain formulas of deflections, cross-section rotations, internal bending moments and transverse forces in the rod with arbitrarily arranged supports and boundary conditions in their intersections.

Equilibrium equations system. We choose a typical coordinate system for bore-hole designs: the $Z$-axis is oriented vertically down, the $X$-axis is directed horizontally in the azimuth at the oil field epicenter. The bending occurs in the vertical surface $X 0 Z$.

Let us consider the arc element of the bent rod with the length $d s$ (Fig. 1). Its upper end is subject to the bending moment $q$, the longitudinal force $t$ and transverse force $u$, whereas the tangent is inclined to the vertical under the zenith angle $\vartheta$. (We denote inclination with $\vartheta$ and curvature with $q$, the symbols suggested by Euler and used by Kirchhoff.). The same forces act on its lower cross-section when the zenith angle increment equals $d \vartheta$. However, they balance the initial forces when increments reach $d q, d t, d u$. The element is also exposed to the rod's distributed weight $j d s$.

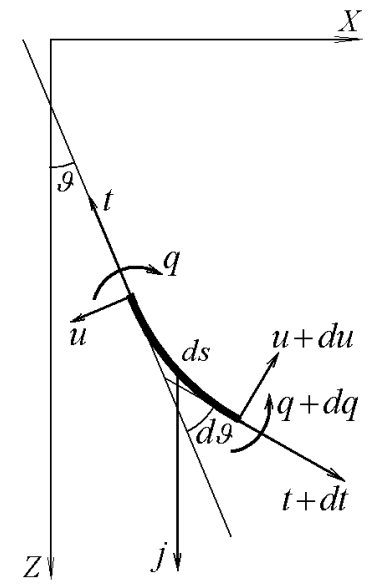

Fig. 1. Equilibrium scheme of the bent element 
The following equations describe force equilibrium projections upon the normal line and tangent

$-u-j d s \sin \vartheta+(u+d u) \cos d \vartheta+(t+d t) \sin d \vartheta=0 ;$

$-t+j d s \cos \vartheta+(t+d t) \cos d \vartheta-(u+d u) \sin d \vartheta=0$.

The moment equilibrium is expressed in this way

$$
\begin{gathered}
-q+(q+d q)+(u+d u) \cos d \vartheta \cdot d s \cos d \vartheta- \\
-(t+d t) \cos d \vartheta \cdot d s \sin d \vartheta=0
\end{gathered}
$$

SoDEs becomes closed due to Euler's kinematic DE determining rod curvature on the same flat surface

$$
q=\vartheta^{\prime}=\frac{d \vartheta}{d s}=\frac{1}{\rho}
$$

where $\rho$ is the curvature radius; prime mark is for derivative with respect to $s$.

Consequently, excessive deformations of a long rod bent in the same plane under its own weight, are described by four heterogeneous SoDEs

$$
\begin{gathered}
u^{\prime}+t \cdot \vartheta^{\prime}=j \sin \vartheta \\
t^{\prime}-u \cdot \vartheta^{\prime}=-j \cos \vartheta \\
q^{\prime}+u=0 \\
\vartheta^{\prime}-q=0
\end{gathered}
$$

where $u$ and $t$ are transverse and longitudinal forces, respectively, acting in the cross-section; $\vartheta$ is an inclination angle of the tangent to the bent $\operatorname{rod} ; j$ is distributed weight; $q$ is curvature (bending moment).

Analytical solution. The obtained system consists of two parts. The first two equations $(1-2)$ depend on a variable $\vartheta$. Obviously, we can exclude a variable $s$ and, after solving the system, find functions $u$ and $t$ relative to a variable $\vartheta$. Then we can find the dependence of $\vartheta$ on $s$ by integrating DE (3-4).

Without the right-hand part, for the homogeneous system of (1-2) to be valid, the Cauchy-Riemann conditions [20] should be satisfied. Therefore, we compress them: set up the product of (2) and the imaginary unit and then find their sum

$$
\begin{gathered}
u^{\prime}+\vartheta^{\prime} t+i t^{\prime}-i \vartheta^{\prime} u=(u+i t)^{\prime}-i \vartheta^{\prime}(u+i t)=Z^{\prime}-i \vartheta^{\prime} Z \\
j \sin \vartheta-i j \cos \vartheta=-i j e^{i \vartheta}
\end{gathered}
$$

where $Z=u+i t$ is a complex function; $i$ is an imaginary unit: $i=\sqrt{-1}$; $e$ is the base of the natural logarithm.

Hence, we get a complex heterogeneous DE

$$
Z^{\prime}-i \vartheta^{\prime} Z=-i j e^{i \vartheta}
$$

Actually, if the homogeneous equation $Z^{\prime}-i \vartheta^{\prime} Z=0$ is integrated by separating variables, it leads to

$$
Z=C e^{i \vartheta},
$$

where $C$ and $D$ are complex integration constants.

When integrating (5) by the Lagrange method [20], we consistently obtain

$$
\begin{gathered}
Z^{\prime}=C e^{i \vartheta} i \vartheta^{\prime}+C^{\prime} e^{i \vartheta}=Z i q+C^{\prime} e^{i \vartheta} \\
C^{\prime} e^{i \vartheta}=-i j e^{i \vartheta} ; \quad C=-i j s+D
\end{gathered}
$$

$$
Z=D e^{i \vartheta}-i j s e^{i \vartheta} .
$$

After solving the Cauchy problem [20], integration constants and the general solution of (5) will have the following representation:

$$
\begin{gathered}
D=Z_{0} e^{-i \vartheta_{0}}+i j s_{0} ; \quad C=Z_{0} e^{-i \vartheta_{0}}-i j\left(s-s_{0}\right) ; \\
Z=Z_{0} e^{i\left(\vartheta-\vartheta_{0}\right)}-i j\left(s-s_{0}\right) e^{i \vartheta},
\end{gathered}
$$

where $s$ is a linear coordinate along the bent bar; index 0 denotes initial parameters in the cross-section with the coordinate $s=s_{0}$.

Let us expand complex functions of the right side (6)

$$
\begin{gathered}
Z_{0} e^{i\left(\vartheta-\vartheta_{0}\right)}=\left(u_{0}+i t_{0}\right)\left(\cos \left(\vartheta-\vartheta_{0}\right)+i \sin \left(\vartheta-\vartheta_{0}\right)\right)= \\
=u_{0} \cos \left(\vartheta-\vartheta_{0}\right)-t_{0} \sin \left(\vartheta-\vartheta_{0}\right)+ \\
+i\left(t_{0} \cos \left(\vartheta-\vartheta_{0}\right)+u_{0} \sin \left(\vartheta-\vartheta_{0}\right)\right) \\
-i j\left(s-s_{0}\right) e^{i \vartheta}=j\left(s-s_{0}\right)(\sin \vartheta-i \cos \vartheta) .
\end{gathered}
$$

By separating real and imaginary parts of the complex function $Z(6)$, we derive answers to (1-2) expressed through the function $\vartheta$

$$
\begin{aligned}
& u=u_{0} \cos \left(\vartheta-\vartheta_{0}\right)-t_{0} \sin \left(\vartheta-\vartheta_{0}\right)+j\left(s-s_{0}\right) \sin \vartheta \\
& t=t_{0} \cos \left(\vartheta-\vartheta_{0}\right)+u_{0} \sin \left(\vartheta-\vartheta_{0}\right)-j\left(s-s_{0}\right) \cos \vartheta
\end{aligned}
$$

Projection method. Frisch-Fay used the projection method to transform $(1-2)$. We propose a shorter way of the problem solution.

Step one: project forces applied to the vertical $Z$. For this purpose, multiply (2) (which shows the force projection on the tangent) by $\cos \vartheta$; multiply (1) (which is the same projection on the normal line) by $-\sin \vartheta$; then add the products obtained

$$
\begin{gathered}
t^{\prime} \cos \vartheta-u \vartheta^{\prime} \cos \vartheta+j \cos ^{2} \vartheta=0 \\
-u^{\prime} \sin \vartheta-t \vartheta^{\prime} \sin \vartheta+j \sin ^{2} \vartheta=0 \\
(t \cos \vartheta)^{\prime}-(u \sin \vartheta)^{\prime}+j=0 .
\end{gathered}
$$

Now project the forces on the horizontal line $X$ by multiplying (1) by $\cos \vartheta$, (2) by $\sin \vartheta$, respectively, and adding the resulting products

$$
\begin{gathered}
u^{\prime} \cos \vartheta+t \vartheta^{\prime} \cos \vartheta-j \sin \vartheta \cos \vartheta=0 \\
t^{\prime} \sin \vartheta-u \vartheta^{\prime} \sin \vartheta+j \cos \vartheta \sin \vartheta=0 \\
(t \sin \vartheta)^{\prime}+(u \cos \vartheta)^{\prime}=0
\end{gathered}
$$

The obtained DE should be integrated

$$
\begin{gathered}
t \cos \vartheta-u \sin \vartheta+j s=c_{1} ; \\
t \sin \vartheta+u \cos \vartheta=c_{2},
\end{gathered}
$$

where $c_{1}$ and $c_{2}$ are integration constants.

Step two: project these equations on the tangent by multiplying (11) by $\cos \vartheta$ and (12) by $\sin \vartheta$, respectively, and adding the respective results

$$
t=c_{1} \cos \vartheta+c_{2} \sin \vartheta-j s \cos \vartheta .
$$

Afterward, project the obtained integrals upon the normal line by multiplying (11) by $-\sin \vartheta$, (12) by $\cos \vartheta$, respectively, and by adding them 


$$
u=-c_{1} \sin \vartheta+c_{2} \cos \vartheta+j s \sin \vartheta
$$

If we proceed to show that for the Cauchy problem in the intersection $s=s_{0}$ of the system (13-14), the outcome is evident

$$
\begin{gathered}
c_{1} \cos \vartheta_{0}+c_{2} \sin \vartheta_{0}=t_{0}+j s_{0} \cos \vartheta_{0} \\
-c_{1} \sin \vartheta_{0}+c_{2} \cos \vartheta_{0}=u_{0}-j s_{0} \sin \vartheta_{0}
\end{gathered}
$$
stants

This system enables us to derive integration con-

$$
\begin{gathered}
c_{1}=t_{0} \cos \vartheta_{0}-u_{0} \sin \vartheta_{0}+j s_{0} \\
c_{2}=t_{0} \sin \vartheta_{0}+u_{0} \cos \vartheta_{0} .
\end{gathered}
$$

Finally, we apply them to formulas (13-14) in order to obtain the solution of system $(1-2)$ in the form of (7-8).

The first integrals. Consider the finite section of the rod bent in the flat surface. In its cross-section with the coordinate $s_{0}$ inclined to the vertical under the angle $\vartheta_{0}$, the bending moment is $q_{0}$. Draw the local $z$-axis and the longitudinal force $t_{0}$ along the tangent and the $x$-axis and the transverse force $u_{0}$ along the normal (Fig. 2).

Then in an arbitrary intersection with the coordinate $s$ inclined to the vertical under the zenith angle $\vartheta$, the bending moment $q$, the axial force $t$ and the transverse force $u$ are directed to balance the initial ones.

For a finite section of the rod $\left[s_{0}, s\right]$, equilibrium equations of force projections on the $z$-axis and on the $x$-axis, respectively, take the following form

$$
\begin{aligned}
& -t_{0}+t \cos \left(\vartheta-\vartheta_{0}\right)-u \sin \left(\vartheta-\vartheta_{0}\right)+\int_{s_{0}}^{s} j d s \cos \vartheta_{0}=0 \\
& -u_{0}+u \cos \left(\vartheta-\vartheta_{0}\right)+t \sin \left(\vartheta-\vartheta_{0}\right)-\int_{s_{0}}^{s} j d s \sin \vartheta_{0}=0
\end{aligned}
$$

Apparently, we can transform them into the first integrals of SoDEs $(1-2)$

$$
\begin{aligned}
& t_{0}=t \cos \left(\vartheta-\vartheta_{0}\right)-u \sin \left(\vartheta-\vartheta_{0}\right)+j\left(s-s_{0}\right) \cos \vartheta_{0} \\
& u_{0}=u \cos \left(\vartheta-\vartheta_{0}\right)+t \sin \left(\vartheta-\vartheta_{0}\right)-j\left(s-s_{0}\right) \sin \vartheta_{0}
\end{aligned}
$$

The solution of this system regarding functions $t$ and $u$ brings $(1-2)$ to the form described by (7-8). Another first integral is derived from the moment equilibrium regarding the current cross-section $s$

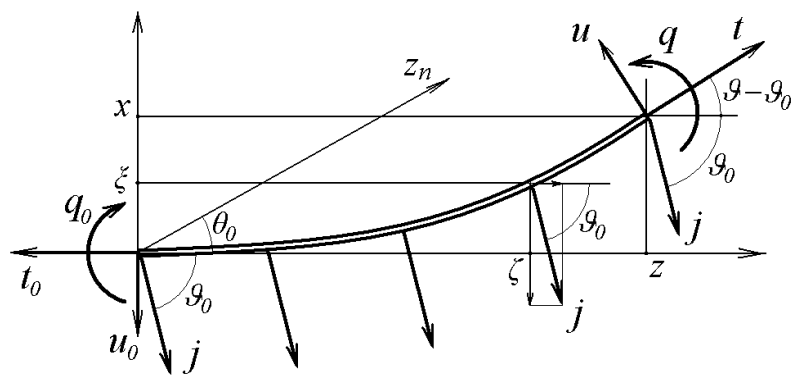

Fig. 2. Equilibrium scheme of the finite area of the curved tube

$$
\begin{gathered}
q-q_{0}-t_{0} x+u_{0} z+j \cos \vartheta_{0} \int_{s_{0}}^{s}(x-\xi) d s+ \\
+j \sin \vartheta_{0} \int_{s_{0}}^{s}(z-\zeta) d s=0 ; \\
q-q_{0}-t_{0} x+u_{0} z+j \cos \vartheta_{0}\left(x\left(s-s_{0}\right)-\int_{s_{0}}^{s} \xi d s\right)+ \\
+j \sin \vartheta_{0}\left(z\left(s-s_{0}\right)-\int_{s_{0}}^{s} \zeta d s\right)=0 .
\end{gathered}
$$

In the chosen local coordinate system the differentials are $d z=\cos \left(\vartheta-\vartheta_{0}\right) d s$ and $d x=\sin \left(\vartheta-\vartheta_{0}\right) d s$.

Differentiation of $s$ eliminates the integrals and is thus sufficient to prove that

$$
\begin{gathered}
q^{\prime}-t_{0} x^{\prime}+u_{0} z^{\prime}+j \cos \vartheta_{0}\left(x^{\prime}\left(s-s_{0}\right)+x \cdot 1-x\right)+ \\
+j \sin \vartheta_{0}\left(z^{\prime}\left(s-s_{0}\right)+z \cdot 1-z\right)=0 ; \\
q^{\prime}-t_{0} \sin \left(\vartheta-\vartheta_{0}\right)+u_{0} \cos \left(\vartheta-\vartheta_{0}\right)+j\left(s-s_{0}\right) \sin \vartheta=0 .
\end{gathered}
$$

This equation can be obtained by plugging the result from (7) into DE (3).

Governing differential equation of the problem is expressed by correlations (3-4) of the original system and the first integral (7)

$$
\begin{gathered}
\vartheta^{\prime \prime}-t_{0} \sin \left(\vartheta-\vartheta_{0}\right)+u_{0} \cos \left(\vartheta-\vartheta_{0}\right)+ \\
+j\left(s-s_{0}\right) \sin \vartheta=0 .
\end{gathered}
$$

This second order DE with variable coefficients is nonlinear due to trigonometric functions; thus, we cannot integrate it into quadrature. However, we assume that it is possible to seek for a solution of (15) not as the function of the angle $\vartheta$, but as the function of its increment $\left(\vartheta-\vartheta_{0}\right)$ on the casing string section between centralizers.

Let us find the form of (15) on the rod segment between the support with a coordinate $s_{0}$ and the second support at the distance $l$ in the direction of increasing $s$ (not shown in Fig. 2), through which a new local axis $z_{n}$ is plotted out (where $n$ is an arbitrary part number). At the upper edge of the segment, the tangent to the bent rod gets deviated from the new axis at an angle $\theta_{0}<0$. Therefore, the zenith angle of the new axis $z_{n}$ to the vertical is $\vartheta_{n}=\vartheta_{0}-\vartheta_{0}$, with $\vartheta_{n}$ being the given angle of the rectilinear rod which was not deformed on the $n^{\text {th }}$ segment between the two supports.

The curvature is caused by the rod weight and bending moments from the two adjacent areas which also undergo some deformation. Hence, the rod cross-sections get deviated regarding the local axis $z_{n}$ at an angle $\theta$. The tangent in them takes its inclination angle regarding the vertical: $\vartheta=\vartheta_{n}+\theta ; \vartheta_{0}=\vartheta_{n}+\theta_{0} ; \vartheta-\vartheta_{0}=\theta-\theta_{0}$. Substituting these angles in (15), we obtain the governing DE of the flexible rod deflection under its own weight

$$
\begin{gathered}
\theta^{\prime \prime}-t_{0} \sin \left(\theta-\theta_{0}\right)+u_{0} \cos \left(\theta-\theta_{0}\right)+ \\
+j\left(s-s_{0}\right) \sin \left(\vartheta_{n}+\theta\right)=0,
\end{gathered}
$$


where $\theta$ is an angle between the tangent at the intersection of the rod and the axis that connects the two hinge supports upon which it rests.

The analysis of trigonometric functions (16) helps us to assess the values acquired in conventional well-bores. On the section between two centralizers at a distance not exceeding $20 \mathrm{~m}$, the curve of pipe column, due to its rigidity, is gently sloping. In the first approximation, it resembles a circular arc. Hence, in the bent part, the inclination angle of the tangent to the support axis varies in the range $\theta_{0} \leq \theta \leq \theta_{l}$, where $\theta_{l}>0$ is the inclination angle of the tangent on the second support $\left(\theta_{l} \approx \mid \theta_{0}\right)$, while the angle increment varies within $0 \leq\left(\theta-\theta_{0}\right) \leq 2\left|\theta_{0}\right|$.

As directional drilling practices prove, the curvature with large-radius curved sections of the bore-hole should not exceed a radius of $160 \mathrm{~m}$. Besides, taking into account the requirements for allowable pipe deflection limit and the necessary clearance between the pipe and hole walls, the distance between centralizers should not exceed $20 \mathrm{~m}$. Under these conditions, the angle $\theta$ varies within \pm 0.063 of the radian $\left( \pm 3^{\circ} .6\right)$. In this case, we accept the values of the functions $\sin \theta=\theta$ and $\cos \theta=1$ with calculation errors of \pm 0.065 and $\pm 0.20 \%$, respectively. At the same time, errors function values from the angle increment $\sin \left(\theta-\theta_{0}\right)=\left(\theta-\theta_{0}\right)$ should not exceed $0.26 \%$ and $\cos \left(\theta-\theta_{0}\right)=1(<0.78 \%)$.

Thereby, taking into consideration technological requirements for the casing in non-vertical and inclined parts of the well, we can linearize the governing DE to calculate rod deformations under its own weight with a reasonable precision

$$
\theta^{\prime \prime}-t_{0}\left(\theta-\theta_{0}\right)+u_{0}+j\left(s-s_{0}\right)\left(\sin \vartheta_{n}+\theta \cos \vartheta_{n}\right)=0,
$$

where $\vartheta_{n}$ is the zenith angle of the support axis.

Application of Airy and Scorer's functions. Let us deal with the Cauchy problem with initial value parameters given on the second support. Hence, $s_{0}=l$, whereas the parameters are indicated by the index $l$

$$
\begin{gathered}
\theta^{\prime \prime}-t_{l}\left(\theta-\theta_{l}\right)+u_{l}+j(s-l)\left(\sin \vartheta_{n}+\theta \cos \vartheta_{n}\right)=0 ; \\
\theta^{\prime \prime}-\left(j \cos \vartheta_{n}(l-s)+t_{l}\right) \theta=j \sin \vartheta_{n}(s-l)-\left(u_{l}+t_{l} \theta_{l}\right),
\end{gathered}
$$

where $l$ is the distance between the two adjacent supports.

If we change the coordinate measurement direction, the previous equivalence will be written as

$$
d^{2} \theta / d s_{*}^{2}-a_{n}^{3}\left(s_{*}+t_{l} / a_{n}^{3}\right) \theta=b_{n}^{3} s_{*}-\left(u_{l}+t_{l} \theta_{l}\right),
$$

where $s_{*}=l-s, a_{n}^{3}=j \cos \vartheta_{n}, b_{n}^{3}=j \sin \vartheta_{n}$.

If we introduce a new variable

$$
\varsigma=a_{n}\left(s_{*}+t_{l} / a_{n}^{3}\right)
$$

then $s_{*}=\left(\varsigma-t_{l} / a_{n}^{2}\right) / a_{n}, d \varsigma / d s_{*}=a_{n}$. Ultimately, the equation looks like

$$
\begin{gathered}
a_{n}^{2} \frac{d^{2} \theta}{d \varsigma^{2}}-a_{n}^{2} a_{n}\left(s_{*}+\frac{t_{l}}{a_{n}^{3}}\right) \theta=\frac{b_{n}^{3}}{a_{n}}\left(\varsigma-\frac{t_{l}}{a_{n}^{2}}\right)-\left(u_{l}+t_{l} \theta_{l}\right) \\
\frac{d^{2} \theta}{d \varsigma^{2}}-\varsigma \theta=\frac{b_{n}^{3}}{a_{n}^{3}} \varsigma-\frac{b_{n}^{3}}{a_{n}^{3}} \frac{t_{l}}{a_{n}^{2}}-\frac{u_{l}+t_{l} \theta_{l}}{a_{n}^{2}} .
\end{gathered}
$$

Inasmuch as $\operatorname{tg} \vartheta_{n}=b_{n}^{3} / a_{n}^{3}$, we use the constant

$$
\mathrm{v}_{l}=\frac{u_{l}+t_{l}\left(\theta_{l}+\operatorname{tg} \vartheta_{n}\right)}{a_{n}^{2}},
$$

and obtain the governing DE describing deformations caused by the weight of the flexible rod placed arbitrarily between two supports

$$
\ddot{\theta}-\varsigma \theta=\varsigma \operatorname{tg} \vartheta_{n}-v_{l},
$$

where $\dot{\theta}=d \theta / d \varsigma$ is a derivative of a new variable.

This is a linear mixed DE of the $2^{\text {nd }}$ order with variable coefficients. As $\ddot{\theta}=\varsigma \theta$ is Airy's homogenous equation, we can rewrite (19) in terms of the linear combination of Airy's functions Ai and Bi (Abramowitz, M. and Stegun, I., eds.)

$$
\theta^{\circ}(\varsigma)=C_{1} \mathrm{Ai}(\varsigma)+C_{2} \operatorname{Bi}(\varsigma)
$$

where $C_{1}$ and $C_{2}$ are integration constants.

Airy's functions can be represented by improper integrals with respect to local parameter $\varphi$ (Abramowitz, M. and Stegun, I., eds.)

$$
\begin{gathered}
\operatorname{Ai}(\varsigma)=\pi^{-1} \int_{0}^{\infty} \cos \left(\varsigma \varphi+\varphi^{3} / 3\right) d \varphi ; \\
\operatorname{Bi}(\varsigma)=\pi^{-1} \int_{0}^{\infty}\left(\sin \left(\varsigma \varphi+\varphi^{3} / 3\right)+\exp \left(\varsigma \varphi-\varphi^{3} / 3\right)\right) d \varphi .
\end{gathered}
$$

If positive values $\varsigma$ increase, Airy's functions monotonically change by the exponential law: $\mathrm{Ai}(\varsigma)$ decreases, $\mathrm{Bi}(\varsigma)$ increases. When the casing is lowered into a curved well-bore in accordance with (17), the function behavior corresponds to the positive tension force of the column, which goes upward: from bottom to top.

For negative values $\varsigma$, Airy's both functions are periodic oscillatory ones. When moving horizontally or close to horizontal parts of the well, the pipe string undergoes longitudinal compression due to friction forces that produce a negative axial force $t$ in its body. Similar deflections are typical of the pipe column, which is consistent with the trigonometric solution of the Euler problem concerning the longitudinal buckling of the rod.

One of the partial solutions of heterogeneous equation (19) is obvious

$$
\theta_{* *}=-\operatorname{tg} \vartheta_{n}
$$

The second partial solution must provide the constant $-v_{l}$ on the right side of (19). First, let us explore the case when the rod portion is under a positive tensile force $t_{l}>0$; hence, according to (18) $v_{l}>0$. With respect to the Lagrange method, integration constants are

$$
C_{1}=\pi v_{l} \int_{0}^{\varsigma} \operatorname{Bi}(\sigma) d \sigma+c_{1} ; \quad C_{2}=-\pi v_{l} \int_{0}^{\varsigma} \operatorname{Ai}(\sigma) d \sigma+c_{2} .
$$

Plugging them into (20) gives

$$
\begin{gathered}
\theta(\varsigma)=c_{1} \operatorname{Ai}(\varsigma)+c_{2} \operatorname{Bi}(\varsigma)-\operatorname{tg} \vartheta_{n}+ \\
+\pi v_{l}\left(\operatorname{Ai}(\varsigma) \int_{0}^{\varsigma} \operatorname{Bi}(\sigma) d \sigma-\operatorname{Bi}(\varsigma) \int_{0}^{\varsigma} \operatorname{Ai}(\sigma) d \sigma\right) .
\end{gathered}
$$

ISSN 2071-2227, Naukovyi Visnyk NHU, 2018, № 6 
The last addend is the second partial outcome that can be expressed as Scorer's function Gi (Abramowitz, M. and Stegun, I., eds.)

$$
\begin{gathered}
\operatorname{Gi}(\varsigma)=\pi^{-1} \int_{0}^{\infty} \sin \left(\varsigma \varphi+\varphi^{3} / 3\right) d \varphi= \\
=\frac{1}{3} \operatorname{Bi}(\varsigma)+\left(\operatorname{Ai}(\varsigma) \int_{0}^{\varsigma} \operatorname{Bi}(\sigma) d \sigma-\operatorname{Bi}(\varsigma) \int_{0}^{\varsigma} \operatorname{Ai}(\sigma) d \sigma\right) .
\end{gathered}
$$

Our further decision extends this relation to equality

$$
\theta(\varsigma)=c_{1} \operatorname{Ai}(\varsigma)+c_{2}^{*} \operatorname{Bi}(\varsigma)+\pi v_{l} \operatorname{Gi}(\varsigma)-\operatorname{tg} \vartheta_{n},
$$

where $c_{2}^{*}=c_{2}-\pi v_{l} / 3$.

Subsequently, we next turn to the case when the rod segment is under the negative compressive force $t_{l}<0$. Keeping in mind that according to (18) $v_{l}<0$, and the right side of (19) contains a positive constant $\left|v_{l}\right|$, the notation of the integration constant and general solution is represented as follows

$$
\begin{aligned}
& C_{1}=-\pi\left|\mathrm{v}_{l}\right| \int_{0}^{\varsigma} \operatorname{Bi}(\sigma) d \sigma+c_{1} ; \quad C_{2}=\pi\left|\mathrm{v}_{l}\right| \int_{0}^{\varsigma} \operatorname{Ai}(\sigma) d \sigma+c_{2} ; \\
& \theta(\varsigma)=c_{1} \operatorname{Ai}(\varsigma)+c_{2} \operatorname{Bi}(\varsigma)-\operatorname{tg} \vartheta_{n}+ \\
&+\pi\left|\mathrm{v}_{l}\right|\left(\operatorname{Bi}(\varsigma) \int_{0}^{\varsigma} \operatorname{Ai}(\sigma) d \sigma-\operatorname{Ai}(\varsigma) \int_{0}^{\varsigma} \operatorname{Bi}(\sigma) d \sigma\right) .
\end{aligned}
$$

Here the last addend can be expressed in terms of Scorer's function Hi (Abramowitz, M. and Stegun, I., eds.)

$$
\begin{gathered}
\operatorname{Hi}(\varsigma)=\pi^{-1} \int_{0}^{\infty} \exp \left(\varsigma \varphi-\varphi^{3} / 3\right) d \varphi= \\
=\frac{2}{3} \operatorname{Bi}(\varsigma)+\left(\operatorname{Bi}(\varsigma) \int_{0}^{\varsigma} \operatorname{Ai}(\sigma) d \sigma-\operatorname{Ai}(\varsigma) \int_{0}^{\varsigma} \operatorname{Bi}(\sigma) d \sigma\right) .
\end{gathered}
$$

Therefore, we obtain equality

$$
\theta(\varsigma)=c_{1} \operatorname{Ai}(\varsigma)+c_{2}^{*} \operatorname{Bi}(\varsigma)+\pi\left|\mathrm{v}_{l}\right| \operatorname{Hi}(\varsigma)-\operatorname{tg} \vartheta_{n}
$$

where $c_{2}^{*}=c_{2}-2 \pi\left|\mathrm{v}_{l}\right| / 3$.

Governing equation (15) and derived equality (19) form the first integral of the initial system (1-4). Therefore, $v_{l}(18)$ is an integration constant which can be calculated from the boundary conditions of the problem.

Taking notice of $(21,23,25)$ and adopting Abramowitz and Stegun's approach (Abramowitz, M. and Stegun, I., eds.), we can claim that the relationship of Airy and Scorer's functions $\mathrm{Bi}(\varsigma)=\mathrm{Gi}(\varsigma)+\mathrm{Hi}(\varsigma)$ allows us to search for the general solution of DE (19) in the form of a linear combination of three linearly independent functions

$$
\theta(\varsigma)=c_{1} \mathrm{Ai}(\varsigma)+c_{2} \mathrm{Gi}(\varsigma)+c_{3} \mathrm{Hi}(\varsigma)-\operatorname{tg} \vartheta_{n},
$$

where $c_{1}, c_{2}$ and $c_{3}$ are integration constants determined by boundary conditions.

Hence, the transverse displacement $x$ of the rod between the supports, internal bending moments $q$ and transverse forces $u$, respectively, imply that

$$
\begin{gathered}
x=\int \theta d s=-a_{n}^{-1} \int \theta d \varsigma= \\
=-a_{n}^{-1}\left(c_{1} \int \mathrm{Ai} d \varsigma+c_{2} \int \mathrm{Gi} d \varsigma+c_{3} \int \mathrm{Hi} d \varsigma-\varsigma \operatorname{tg} \vartheta_{n}+c_{4}\right) ; \\
q=\theta^{\prime}=-a_{n} \dot{\theta}=-a_{n}\left(c_{1} \dot{\mathrm{Ai}}(\varsigma)+c_{2} \dot{\mathrm{G}}(\varsigma)+c_{3} \dot{\mathrm{Hi}}(\varsigma)\right) ; \\
u=-q^{\prime}=a_{n} \dot{q}=-a_{n}^{2}\left(c_{1} \ddot{\mathrm{A}}(\varsigma)+c_{2} \ddot{\mathrm{G}} \mathrm{i}(\varsigma)+c_{3} \ddot{\mathrm{Hi}}(\varsigma)\right),
\end{gathered}
$$

where $d s=-a_{n}^{-1} d s$ according to (17).

The Ai function is the key to Airy's homogeneous equation, while the functions $\mathrm{Gi}$ and $\mathrm{Hi}$ are solutions of Airy's heterogeneous equation (Abramowitz, M. and Stegun, I., eds.); therefore,

$$
\begin{gathered}
\ddot{\mathrm{Ai}}(\varsigma)=\varsigma \mathrm{Ai}(\varsigma) ; \\
\ddot{\mathrm{G}} \mathrm{i}(\varsigma)=\varsigma \mathrm{Gi}(\varsigma)-\pi^{-1} ; \quad \ddot{\mathrm{Hi}}(\varsigma)=\varsigma \mathrm{Hi}(\varsigma)+\pi^{-1} ; \\
u=-a_{n}^{2}\left(\varsigma\left(c_{1} \operatorname{Ai}(\varsigma)+c_{2} \operatorname{Gi}(\varsigma)+c_{3} \operatorname{Hi}(\varsigma)\right)-\left(c_{2}-c_{3}\right) \pi^{-1}\right) .
\end{gathered}
$$

Proceeding from the results in $(24,26,27)$, we get $u=-a_{n}^{2}\left(\left(\theta+\operatorname{tg} \vartheta_{n}\right) \varsigma-v_{l}\right)$.

The support coordinates at $s=0$ and $s=l$ are $\varsigma_{0}=$ $=a_{n} l+t_{l} / a_{n}^{2}$ and $\varsigma_{l}=t_{l} / a_{n}^{2}$, respectively. Two boundary conditions are non-availability of support deflections: $x\left(\varsigma_{0}\right)=0 ; x\left(s_{l}\right)=0$. The other two boundary conditions are equations of the compatibility of rotation angles and bending moment equilibrium of supporting cross-sections on the two sides of the adjacent parts of the rod. At the free edge of the tube column $q\left(s_{l}\right)=0$.

Series application. Two linearly independent series satisfy Airy's homogeneous equation

$$
\begin{gathered}
\theta_{A}=1+\frac{\varsigma^{3}}{3 !}+\frac{4}{6 !} \varsigma^{6}+\frac{4 \cdot 7}{9 !} \varsigma^{9}+\frac{4 \cdot 7 \cdot 10}{12 !} \varsigma^{12}+\ldots \\
\theta_{B}=\varsigma+\frac{2}{4 !} \varsigma^{4}+\frac{2 \cdot 5}{7 !} \varsigma^{7}+\frac{2 \cdot 5 \cdot 8}{10 !} \varsigma^{10}+\frac{2 \cdot 5 \cdot 8 \cdot 11}{13 !} \varsigma^{13}+\ldots .
\end{gathered}
$$

Eventually, we might conclude that heterogeneous equation $\ddot{\theta}-\varsigma \theta=1$ fits into the series

$$
\theta_{*}=\frac{\varsigma^{2}}{2 !}+\frac{3}{5 !} \varsigma^{5}+\frac{3 \cdot 6}{8 !} \varsigma^{8}+\frac{3 \cdot 6 \cdot 9}{11 !} \varsigma^{11}+\frac{3 \cdot 6 \cdot 9 \cdot 12}{14 !} \varsigma^{14}+\ldots .
$$

The general solution of DE (19) is a linear combination of three linearly independent series (28-30) and the partial answer derived from (22)

$$
\theta=c_{1} \theta_{A}+c_{2} \theta_{B}+c_{3} \theta_{*}-\operatorname{tg} \vartheta_{n} .
$$

In particular, the formulas for $x, q, u$ are defined as

$$
\begin{gathered}
x=-a_{n}^{-1}\left(c_{1} \int \theta_{A} d \varsigma+c_{2} \int \theta_{B} d \varsigma+c_{3} \int \theta_{*} d \varsigma-\varsigma \operatorname{tg} \vartheta_{n}+c_{4}\right) ; \\
q=-a_{n}\left(c_{1} \dot{\theta}_{A}+c_{2} \dot{\theta}_{B}+c_{3} \dot{\theta}_{*}\right) ; \\
u=-a_{n}^{2}\left(c_{1} \ddot{\theta}_{A}+c_{2} \ddot{\theta}_{B}+c_{3} \ddot{\theta}_{*}\right)=-a_{n}^{2}\left(\left(\theta+\operatorname{tg} \vartheta_{n}\right) \varsigma-v_{l}\right) .
\end{gathered}
$$

Clearly, integration constants $c_{1}, c_{2}, c_{3}=-v_{l}$ and $c_{4}$ should be determined by boundary conditions.

Applying results. The formulas obtained provide technological conditions for casing pipe installation in the bore-hole. In particular, the equation of transverse displacements can determine maximum pipe deflection 
$x_{\max }$ in the middle of the section setting an allowable distance $l_{\max }$ between centralizers to reduce the deflection concerned. The values of the bending moments $q_{\max }$ in supporting cross-sections make it possible to calculate maximum bending tensions

$$
\sigma_{\max }=q_{\max } E d / 2,
$$

where $d$ is the casing pipe diameter.

Conclusions. This article presents a valid mathematical tool based on the heterogeneous system of four DEs describing large deformations of a long elastic rod buckled under its own weight in one plane. Technological requirements for the casing resting on centralizers in nonvertical and curved wells taken into account, it is possible to linearize the first integral of the system and reduce it to the second order heterogeneous DE with variable coefficients. Its solution is a combination of Airy's and Scorer's functions or three linearly independent polynomial series with a partial answer.

The suggested numerical considerations can find their further development in modeling casing deformation scenarios in real conventional bore-holes. The current approach applies the equation system describing deformation compatibility and moment equivalence in the supporting cross-sections of each centralizer along the string length. Since it is still a challenge to calculate casing buckling, the detailed deduction procedure can contribute to computational practices in drilling engineering. This buckling solution of casing pipes can serve to check the validity, compatibility, and accuracy of numerical methods.

The obtained equations of deformation and force parameters allow us to calculate the casing pipes stressstrain in bore-holes of arbitrary profiles. As these mathematical tools can be an efficient and accurate key to determining the casing string buckling, they can increase the well-bore reliability and durability.

\section{References.}

1. Brusco, G., Lewis, P. and Williams, M., 2004. Drilling straight down. Oilfield Review [pdf], 16(3), pp. 1417. Available at: <https://www.slb.com/ /media/Files/ resources/oilfield_review/ors04/aut04/02_drilling_ straight_down.pdf $>$ [Accessed 4 November 2017].

2. Williams, M., 2004. Better turns for rotary steerable drilling. Oilfield Review [pdf], 16(1), pp. 4-9. Available at: <https://www.slb.com/ /media/Files/resources/ oilfield_review/ors04/spr04/01_rotary_steerable_drilling.pdf $>$ [Accessed 23 December].

3. McDermott, J. R., Viktorin, R. A. and Schamp, J. H., 2005. Extended reach drilling (ERD) technology enables economical development of remote offshore fields in Russia. In: SPE/IADC Drilling Conference. Amsterdam, Netherlands: Society of Petroleum Engineers [online], pp. 183-188. Available at: <https://www.onepetro.org/ conference-paper/SPE-92783-MS> [Accessed 4 November 2017].

4.Gupta, V. P., Yeap, A. H., Fischer, K. M., Mathis, R. S. and Egan, M. G., 2014. Expanding the extended reach envelope at Chayvo field, Sakhalin island. In: $I A D C /$ SPE Drilling Conference and Exhibition. Fort Worth, Texas, US: Society of Petroleum Engineers [online], pp.
1207-1229. Available at: <https://www.onepetro.org/ conference-paper/SPE-168055-MS $>$ [Accessed 22 December 2017].

5. Kotskulych, Ya.S., Seniushkovych, M.V., Martsynkiv, O. B. and Vytvytskyi, I. I., 2015. Casing string centering in directional wells. Naukovyi Visnyk Natsionalnoho Hirnychoho Universytetu, 3(147), pp. 23-30.

6. Vytvytskyi, I. I., Seniushkovych, M. V. and Shatskyi, I. P., 2017. Calculation of distance between elasticrigid centralizers of the casing. Naukovyi Visnyk Natsionalnoho Hirnychoho Universytetu, 5, pp. 29-35.

7. Gulyayev, V. and Shlyun, N., 2016. Influence of friction on buckling of a drill string in the circular channel of a borehole. Petroleum Science, 13, pp. 698-711.

8. Musa, N.W., 2017. Elastic bending deformation of the drill strings in channels of curve wells. Modern Mechanical Engineering, 7, pp. 1-7.

9. Timoshenko, S. P. and Gere, J. M., 2012. Theory of Elastic Stability [e-book]. New York: Dover Publications. Available at: <https://books.google.com.ua/ books?id=98B6JO W2HiUC\&lpg=PP1\&dq=inauthor \%3A\%22Stephen\%20P.\%20Timoshenko\%22\&hl=uk\& $\mathrm{pg}=\mathrm{PP} 1 \mathrm{Av}=$ onepage $\& \mathrm{q} \& \mathrm{f}=$ false $>$ [Accessed 11 October 2017].

10. Azar, J.J. and Samuel, G. R., 2007. Drilling Engineering [e-book]. Oklahoma: PennWell Books. Available at: <https://books.google.com.ua/books?id=eseVi O982VgC\&lpg=PP1\&dq=inauthor\%3A\%22Jamal\%20 $\mathrm{J} . \% 20 \mathrm{Azar} \% 22 \& \mathrm{hl}=\mathrm{uk} \& \mathrm{pg}=\mathrm{PR} 7 \# \mathrm{v}=$ onepage $\& \mathrm{q} \& \mathrm{f}=\mathrm{f}$ alse $>$ [Accessed 9 December 2017].

11. Eryılmaz, A., Atay, M.T., Coskun, S. B. and Başbük, M., 2013. Buckling of Euler Columns with a Continuous Elastic Restraint via Homotopy Analysis Method. Journal of Applied Mathematics, 8 pgs. DOI: $10.1155 / 2013 / 341063$.

12. Jiuping, $\mathrm{Xu}$ and Zezhon, $\mathrm{Wu}, 2015$. Tubular String Characterization in High Temperature High Pressure Oil and Gas Wells. London: CRC Press.

13. Byrom, T. G., 2014. Casing and Liners for Drilling and Completion: Design and Application [e-book]. Oxford: Elsevier Gulf Professional Publishing. Available at: $<$ https:// books.google.com.ua/books?id=qQd0AwAA QBAJ\&1pg=P P1\&dq=inauthor $\% 3$ A $\% 22$ Ted $\% 20$ G.\%20Byrom $\% 22 \& \mathrm{hl}=\mathrm{uk} \& \mathrm{pg}=\mathrm{PP} 1 \# \mathrm{v}=$ onepage $\& \mathrm{q} \& \mathrm{f}$ $=$ false $>$ [Accessed 4 October 2017].

14. Renpu, Wan, 2011. Advanced Well Completion Engineering [e-book]. Oxford: Elsevier Gulf Professional Publishing. Available at: <https://books.google.com. ua/books ?id=GH6JoDxT_9sC\&lpg=PP1\&dq=inauth or\%3A\%22Wan\%20Renpu\%22\&hl=uk\&pg=PP1\#v=o nepage $\& \mathrm{q} \& \mathrm{f}=$ false $>$ [Accessed 9 January 2018].

15. Oriji, B.A. and Anwana, M.E., 2017. Design and Analysis of Drilling String Buckling in Directional Wells. International Journal of Current Engineering and Technology, 7(6), pp. 2062-2069.

16. Xie, J., 2006. Casing Design and Analysis for Heavy Oil Wells. In: 1st World Heavy Oil Conference, Paper 2006-415 [online]. Available at: <https://www.research gate.net/publication/308708966_Casing_Design_and_ Analysis_for_Heavy_Oil_Wells> [Accessed 22 December 2017]. 
17. Hossain, M. E. and Islam, M. R., 2018. Drilling Engineering Problems and Solutions: A Field Guide for Engineers and Students [e-book]. Beverly: Scrivener Publishing. Available at: <https://books.google.com.ua/books ?id=PPRgDwAAQBAJ\&lpg=PP1\&dq=inauthor\%3A $\% 22$ M.\%20E.\%20Hossain $\% 22 \& \mathrm{hl}=\mathrm{uk} \& \mathrm{pg}=\mathrm{PT} 1 \# \mathrm{v}=\mathrm{O}$ nepage \&q\&f=false $>$ [Accessed 4 October 2017].

18. Jaculli, M.A. and Mendes, J. R. P., 2018. Dynamic Buckling of Columns Inside Oil Wells [e-book]. Springer Briefs in Petroleum Geoscience \& Engineering, Springer. Available at: <https://books.google.com.ua/books? $\mathrm{id}=9 \mathrm{E} 5 \mathrm{aDwAAQBAJ} \& \mathrm{lpg}=\mathrm{PR} 1 \& \mathrm{dq}=$ inauthor $\% 3 \mathrm{~A} \%$ 22Marcelo\%20Anuncia\%C3\%A7\%C3\%A3o\%20Jacull $\mathrm{i} \% 22 \& \mathrm{hl}=\mathrm{uk} \& \mathrm{pg}=\mathrm{PR} 4 \# \mathrm{v}=$ onepage $\& \mathrm{q} \& \mathrm{f}=$ false $>[$ Accessed 2 March 2018].

19. Paliichuk, I. I., 2017. Method for determining the internal force factors in the casing column of the deep spatially oriented wells. Prospecting and Development of Oil and Gaz. Fields, 2(63), pp. 44-50.

20. Adkins, W. and Davidson, M. G., 2012. Ordinary Differential Equations [e-book]. New York: Springer. Available at: <https:// www.springer.com/us/book/ 9781461436171> [Accessed 4 October 2017].

\section{Великі деформації обсадної колони під дією власної ваги у криволінійній свердловині}

\section{Є. І. Крижсанівський, I. І. Палійчук, Г. Д. Малик}

Івано-Франківський національний технічний університет нафти і газу, м. Івано-Франківськ, Україна, е-таil: rector@nung.edu.ua; paliychuk.igor.if@gmail.com

Мета. Визначення рівнянь деформаційних і силових параметрів, що описують напружено-деформований стан обсадної колони на невертикальних ділянках свердловини.

Методика. Колона обсадних труб у криволінійній свердловині працює як довгий нерозрізний стрижень Його великі деформації з урахуванням власної ваги описані неоднорідною системою чотирьох диференціальних рівнянь. Урахування вимог технології встановлення колони труб у свердловині на центрувальних опорах дозволяє лінеаризувати перший інтеграл системи.

Результати. Встановлено, що деформування пружного стрижня під дією поздовжньої й поперечної складових сил розподіленої ваги описується неоднорідним диференціальним рівнянням другого порядку зі змінними коефіцієнтами. За його розв'язком знайдені вирази прогинів, кутових деформацій, внутрішніх згинальних моментів і поперечних сил у стрижні з довільним розташуванням опор і граничними умовами в опорних перетинах.

Наукова новизна. Знайдено розв'язок основного диференціального рівняння кутових деформацій довгого стрижня у вигляді лінійної комбінації функцій Ейрі й Скорера та у вигляді трьох лінійно незалежних поліноміальних рядів у сумі з частинним розв'язком.

Практична значимість. Одержані вирази деформаційних і силових параметрів дають змогу розрахувати напруження й деформації труб обсадної колони під час технологічного процесу кріплення свердловини довільного профілю, що дозволяє підвищити надійність і довговічність іiі експлуатації.

Ключові слова: криволінійна свердловина, обсадна колона, пружний стрижень, деформації згину, функції Ейрі, функції Скорера

\section{Болышие деформации обсадной колонны под действием собственного веса в криволинейной скважине}

\section{Е. И. Крыжканивский, И. И. Палийчук, Г. Д. Малик}

Ивано-Франковский национальный технический университет нефти и газа, г. Ивано-Франковск, Украина, e-mail: rector@nung.edu.ua; paliychuk.igor.if@gmail.com

Цель. Определение уравнений деформационных и силовых параметров, которые описывают напряженно-деформированное состояние обсадной колонны на невертикальных участках скважины.

Методика. Колонна обсадных труб в криволинейной скважине работает как длинный неразрезной стержень. Его большие деформации с учетом собственного веса описаны неоднородной системой четырех дифференциальных уравнений. Учет требований технологии установки колонны труб в скважине на центрирующих опорах позволяет линеаризировать первый интеграл системы.

Результаты. Установлено, что деформирование упругого стержня под действием продольной и поперечной составляющих сил распределенного веса описывается неоднородным дифференциальным уравнением второго порядка с переменными коэффициентами. По его решению найдены выражения прогибов, угловых деформаций, внутренних изгибающих моментов и поперечных сил в стержне с произвольным расположением опор и граничными условиями в опорных сечениях.

Научная новизна. Найдено решение основного дифференциального уравнения угловых деформаций длинного стержня в виде линейной комбинации функций Эйри и Скорера и в виде трех линейно независимых полиномиальных рядов в сумме с частным решением.

Практическая значимость. Полученные выражения деформационных и силовых параметров позволяют рассчитать напряжения и деформации труб обсадной колонны во время технологического процесса крепления скважины произвольного профиля, что позволяет повысить надежность и долговечность ее эксплуатации.

Ключевые слова: криволинейная скважина, обсадная колонна, упругий стержень, деформации изгиба, функции Эйри, функции Скорера

Рекомендовано до публікації докт. техн. наук В.М.Мойсишиним. Дата надходження рукопису 07.11.17. 